\title{
Adaptation Strategies after Cyclone in Southwest Coastal Bangladesh - Pro Poor Policy Choices
}

\author{
Zakia Sultana ${ }^{1}$, Bishawjit Mallick ${ }^{2,3, *}$ \\ ${ }^{1}$ Environmental Science Discipline, Khulna University, Khulna, Bangladesh \\ ${ }^{2}$ Institute of Regional Science (IfR), Karlsruhe Institute of Technology (KIT), Karlsruhe, Germany \\ ${ }^{3}$ Foreign Research Fellow at Political Science Department of Vanderbilt University, Nashville, USA \\ *Corresponding author: bishawjit_mallick@biari.brown.edu, bishawjit.mallick@kit.edu
}

Received July 03, 2015; Revised July 13, 2015; Accepted July 23, 2015

\begin{abstract}
People live under the constant threats of natural hazards in the coastal areas all over the world. Thus raise the questions: how do they react to the risk of those natural calamities and how do they adapt with the adverse situations that are derived by those calamities. Taking these into considerations, this research explores the 'atlas of the locally adopted strategies' to cope with adverse effects of cyclone Aila in southwest coastal Bangladesh. Particularly, this research has explored the community level practices in agriculture, housing, water resources, communication and employment generations. An empirical survey was undertaken with 145 respondents by using semi-structured interviews with selected social groups and their households' assistants. Besides face-to-face interviews, this survey applied group level qualitative assessment methods i.e. FGD (focus group discussion), Social Domain Analyses, and In-depth Interviews to collect the data. Results show that people have started to cultivate saline tolerant rice and vegetables on raised homesteads. They are using dripping irrigation methods. Rain water harvesting and artificial aquifer tube-well have been introduced for water management. The houses' mud walls have been replaced by or even newly rebuilt with Goran wood or bamboo sticks to save lives. They have formed groups to save money for the next disaster and taken out loans for small entrepreneurship projects. Due to the crises of fodder, pastureland and freshwater, people have started to rear small animals and birds like sheep, goat and pigeon instead of cow and buffalo. New technology based shrimp farming is another new innovation. Discussions were held on the pros and cons of all of the above strategies that help to design the long-term risk reduction planning at the local level and addresses the 'not the need-based planning but the acceptance-based strategies' mantra of development in context of community based disaster management planning. This paper adds values to the climate change adaptation field by addressing the acceptance of modern disaster risk reduction technologies into a traditionally modified approach based on the empirical evidence of coastal livelihood analysis in Bangladesh.
\end{abstract}

Keywords: local adaptation strategies, disaster risk reduction planning, community based management, Bangladesh, pro-poor policy choice

Cite This Article: Zakia Sultana, and Bishawjit Mallick, "Adaptation Strategies after Cyclone in Southwest Coastal Bangladesh - Pro Poor Policy Choices.” American Journal of Rural Development, vol. 3, no. 2 (2015): 24-33. doi: 10.12691/ajrd-3-2-2.

\section{Introduction}

Every individual perceives hazardous events with their own capacity to cope with its adverse effect and interacts with their surroundings accordingly. Risk reduction strategies highlight a community's ability to reduce their own disaster risk, through the identification of those directly impacted by hazards as those best placed to identify solutions for risk reduction [4,21]. Each social system response in a crisis situation and the temporary adaptive process may be transferable as a permanent pattern for that society if the disasters take place again and again [1]. Disaster risk reduction strategies and adaptation practices vary from region to region and community to community; for example, the practices of southern part of Bangladesh are different from the northern part. The sustainable disaster risk reduction strategies or adaptation practices of one region may be not be replicable in another region or community but the learnings from each strategies can introduce a new strategy that is adoptable to the respective region. Therefore, this research will identify the short-term and long-term adopted strategies that are implemented after a devastated cyclone in southwest coastal Bangladesh.

External aid must not be the only solution to increase the coping capacity of a community, nor will a more resilient community be developed through help from different organizations. This research is focused on building resilience in affected communities by empowering regional planners and policy makers with better data to build a comprehensive disaster management plan. To do so, this research will discuss the measures/strategies that were taken by various actors based on their existing socio-economic conditions as well 
as the positive and negative consequences of those adopted strategies. The pros and cons of each adopted strategies states the interests of the different actors behind the respective strategy. This study is therefore of importance to regional planners and policy makers to help them develop a comprehensive disaster management plan (ex-post) that will also helpful in building resilience in the affected communities.

This article is organized in 5 sections: (1) Introduction, (2) Importance of this research in Bangladesh based on the literature review, (3) Study area description and methodology, (4) Results, and (5) Open discussion and conclusion.

\section{State-of-the-art}

Few decades ago, disasters were viewed as one-off events and responded to by governments and relief agencies without taking into account the social and economic implications and causes of these events [12,34]. Nowadays climate change adds a new dimension to the disaster events. Due to climate change the frequency, magnitude, intensity and extension of disaster increases more than the previous records [31]. The rapid increase in temperature and change in rainfall pattern causes negative impact on the agriculture, livelihood, and water management sectors which increases socioeconomic vulnerabilities [1,32]. Both natural and climate change induced disasters cannot be prevented but its impacts can be reduced by taking sustainable disaster risk reduction strategies. O’Brien et al. [8] emphasized that disaster risk reduction and climate change adaptation are of critical importance to the security of millions of people, and that vulnerability reduction can serve as a cornerstone for strategies to reduce the negative outcome of climate change. However, can the vulnerability to disaster risk be reduced by external interventions? A simple clarification about this question based on different literature is given below:

\subsection{External versus Community Driven Interventions}

Historically, households affected by a natural disaster take the "Charity initiative" as a short-term strategy [35]. They pay little attention to long-term measures as they always strive for an immediate solution. These various programs of disaster management have few long-term goals and approaches [20], although disasters always have long-term impact on the affected community [26]. The consequences of natural disasters could bring permanent problems for the poor because they cause not only a loss of income, but also the loss of their possessions [7]. In addition, the poor sometimes take short-term measures which may cause long-term negative consequence [13]. Short-term restrictions on the recovery of a household can cause poverty traps and on the other hand lead to a reduction of the long-term macro-economic growth of a country $[5,14]$. The modern risk management approach recognizes that a wide range of geological, meteorological, environmental, technological and socio-political hazards threaten society by their complex interactions. Therefore, disaster risk management should be an integral part of the way organizations do their work, not an add-on or on-off action [6]. The following section addresses how the changes in a society taken place after a disaster.

\subsection{Consequences of Disaster to the Affected Community}

In general, coastal communities experience more major natural disasters than in-land communities. In recent years the trend of coastal disasters has (also been increasing. These events change the societies in different ways, for example they (re)structure the income opportunities, (re)build the infrastructures and institutions, (re)structure the social-power structure, or even renew the settlement pattern $[15,24]$. Although the community is given greater roles in the decision-making and implementation processes, the community based disaster management (CBDM) approach acknowledges the importance of masslevel participation for executing a community management plan with the end goal of increasing capacities and transferring resources to the community.

Actually the level of changes and significance of societal changes totally depend on the adopted strategies by the individuals. This paper explores those changes that occur at individual household level. This study selects mostly practiced and observed strategies adopted by the cyclone Aila of 2009 affected southwest coastal community in Bangladesh and then discusses its' consequences on the studied community. Particularly, it focuses on the changes in households' assets at first. Secondly it delves into the changes of income opportunities. Then it explores the influence of microcredit program after the cyclones. Finally it elaborates 'temporary displacement after cyclone', one of the frequently adopted strategies to combat natural hazards.

Sequential coping strategies applied to respond to disturbances can be divided into two groups: ex-ante risk management strategies and ex-post coping strategies [16]. The present research on ex-post coping strategy in disaster management is mainly focused on the negative effects of a disaster. The ex-post coping strategies can be divided between mechanisms within the household (internal) and carried out by organizations strategies (external). Previous studies [27] on the drought in Kenya [5] and on vulnerability and poverty in India [28], have dealt with the ex post coping mechanisms. These studies mainly focus on both the internal policies and external strategies. In addition, less attention has been paid by the authors $[9,23,30]$ to look at the damage caused by natural disasters taking into account both internal and external policies of the coastal communities of Bangladesh. Therefore, the present study intends to explore various ex-post coping measures (which can be considered ex-ante for the next upcoming cyclone) to examine internal and external sides and their impact on coastal communities.

\subsection{Why Bangladesh?}

Due to its geographical location, Bangladesh is the most disaster-prone country in South Asia [3]. It is a poor country and faces many impacts from climate change in the form of severe cyclones, floods, droughts, rises in sea level, storm surges and severe salinity increases affecting the population, their livelihoods, their health, socioeconomic systems, natural environments, and water 
sources [11,33]. The coastal zone of Bangladesh is one of the top 10 potentially-vulnerable locales and an increase in sea level of one meter would lead to an additional 15 million landless people in Bangladesh who would become environmental refugees [11]. Between 1877 and 2009, Bangladesh was hit by 159 cyclones, including 48 severe cyclonic storms, 43 cyclonic storms and 68 tropical depressions [25]. On average, Bangladesh is struck by a severe cyclone every three years $[11,18]$.

The inundation possibilities due to 1 meter sea level rise would not only entail the loss of agricultural land, but would also destroy the existing settlements, roads and communication infrastructure. Another significant problem in addition to the geographical factors in the southwestern coastal region is the fact that the socioeconomic situation of coastal populations is often precarious. The livelihood of coastal households is generated primarily by agriculture. Consequently, the people would have to move away from these places. For example, Rita Afsar [2] revealed that almost two-fifths of rural households in Bangladesh sent their adult members to the nearest towns due to lack of year-round employment. This situation becomes worse in the aftermath of a disaster, providing both an impetus and a justification to leave the area.

The above circumstances made the livelihood of the residents in the coastal region very difficult. The last destructive cyclone that struck the southwest coastal area of Bangladesh on May 25, 2009 was considered a Category 1 cyclone on the Saffir-Simpson Hurricane Scale (category 1 = wind speed $119-153 \mathrm{~km} / \mathrm{h}$ ). After this cyclone, "Cyclone Aila”, about 2.3 million people were affected and 237 people lost their lives and the country suffered essential infrastructure damage [23]. During the cyclone, the storm surge was up to three meters above sea level $[19,24]$. Thus, the dams in many places were flooded and destroyed and so many villages and agricultural land were flooded. The people in the affected areas lost their livelihoods, their homes, shrimp farms, farmland and livestock. As many areas were inundated by high concentrations of salt water, the soil became too salty to grow rice. Residents in these area after this cyclone could no longer pursue agriculture [24].

In the critical time shortly after the cyclone Alia, affected households suffered from a shortage of adequate food, drinking water, medical care, etc. $[19,24]$. Since the cyclone has seriously affected the normal livelihood of the people, after the emergency period ended many victims still struggle against the damage caused by Aila to survive and return to a normal life. Various initiatives have been taken to address the critical situation [24]. Since there were no employment opportunities after the cyclone in this region many household members moved in a different region or city. Sometimes an entire family moved to another region or city $[17,26]$. This emergency period after the cyclone isn't very well define here. I understand what you mean but it is difficult to work with grammatically as this time period does not have a clear definition.

It is also important to mention that after the emergency situation of the cyclone Aila, the government carried out a rapid initial damage and needs assessment. The allocation of resources from state and international humanitarian organizations was not enough. There were subjective group interests involved which resulted in inefficient allocation of resources [19]. Therefore, the NGOs and Union Parishad conducted a detailed assessment and the beneficiaries (who gets the help) of each electoral districts (Union Parishad) selected [19]. But while the selection of beneficiaries, there was corruption and injustice, for example, have relatives or acquaintances of auxiliary distributors, people of a particular political party or locally powerful individuals, taken advantage [22,24]. Sometimes here fell out of the coordination between the organizations.

Even after a cyclonic-related disaster, local actors try to not only survive but to gain an advantage over others and improve their position of power within the local community or to even make money on this disaster. Therefore within the selection of beneficiaries there are cases of corruption and injustice as relatives and acquaintances of auxiliary distributors, actors from particular political parties or locally important actors tried to obtain advantage [22]. These cases are fundamentally important to this analysis and deserve further investigation. This empirical research attempts to include these considerations on adopted ex post coping strategies and their consequences on the livelihood of communities through the case study site of Atulia Union of Shyamnagor Upazila of Satkhira district.

\subsection{Case Study Site - Atulia Union, Shyamnagor Upazila, Satkhira district}

The study area is located between $22^{\circ} 17^{\prime}$ to $22^{\circ} 22^{\prime}$ North and between $89^{\circ} 8^{\prime}$ to $89^{\circ} 13^{\prime}$ East. According to the Bangladesh Bureau of Statistics, this area has a population of 37,065 and 7,744 households. About $90 \%$ of these houses cannot withstand a cyclone. Total cultivable land of this union is 1,166 hectors, barren land is 320 hectors and temporary barren land is 1,214 hectors. According to Fisheries Department of Shyamnagar upazila, there are 137 Shrimp farms and total shrimp production in 2012 was 80.2 metric ton. Biodiversity is threatened day by day in the study area; big trees are all gone, tree species like mango and jackfruit which were once common are now all gone. Now trees like tan, sour and bitter fruit-bearing trees do well in the area. People can't rear the cows because cows can't survive in this area. The number of birds is decreasing day by day.

The seasonal change in temperature is almost constant throughout the year. In winter months from December to February the temperature range is between $11^{\circ} \mathrm{C}$ to $25^{\circ} \mathrm{C}$. In the period from March to May the temperature rises to $30^{\circ} \mathrm{C}$ and in the monsoon season from June to September the temperature remains at a little below $30^{\circ} \mathrm{C}$. Temperature starts to fall in October. Rainfall amount is high in the monsoon season at more than $250 \mathrm{~mm}$. The highest recorded monthly total rainfall is $641 \mathrm{~mm}$ in the month of August, 2011. The amount of rainfall is zero in the month of November to January even to February. A heavy rainfall is common in the study area that occurs two or three times in a year. Maximum average relative humidity for the study area was 90.3\% in July 2006 and August 2007. Minimum average relative humidity was recorded at $67.3 \%$ in March 2006. In the winter period humidity is reduced from $80 \%$. In March humidity is reduced to the lowest level. After March humidity exceeds. 


\section{Materials and Methods}

This research consists of a two stage empirical survey. The first one comprises the socio-economic data, that deals with the face-to-face questionnaire survey and interview method that was used in the field. It helped to get the individual households' socio-economic pattern along with other influential determinants for livelihood. The questionnaire consists of both open-ended and closedended type questions. The open-ended questions helped to obtain the diversity of information, particularly for the immediate response towards a climatic shock. Informal discussion method was used to gather information on the proposed study and to strengthen bonds with the potential interviewees but not as prime method to collect the data. The same method was adopted to collect the information regarding social structures in the study villages.

The second part of empirical research concerns the qualitative study. The analyses follow a mixed-methods approach combining content analysis of face-to-face interview of 145 respondents by using semi-structured interviews with selected social groups and their households' assistants. As this second part of empirical research was aimed at specific, contingent debates concerning their local attitude and perception for the improvement of their livelihood, it was understood as a case-study of livelihood complexities in coastal areas. Therefore, Focus Group Discussion (FGD) was conducted with three different groups: farmers, fishermen and general people. Key informant interviewers (KII) were: chairman of the Union, Upazila Agricultural officer, Upazila Fisheries Officer, NGO Representatives. Sector wise disaster risk reduction strategies and adaptation practices are recognized by the discussion with the FGD participants.

During FGD a seasonal hazard-calendar of the community was drawn that shows the local patterns of hazards. The timing of disasters varies depending upon the local climatic conditions. The intensity of each disaster varies from month to month and even within the month. The FGD participants were asked the timing of occurrence of each disaster by mentioning the Bengali month and intensity and magnitude of the disaster in terms of high, medium and low. According to the participants, the change of weather and climatic conditions has changed with the nature of disasters and there are marked differences in the magnitude of the losses observed from the nature of disasters. The significant natural events in the history of the community hitherto kept in oral form are documented. A core set of trends should include changes in cyclone, flood, drought, etc. Thereby the adopted strategies against the hazardous event were also discussed. The practices which are found from the discussion were observed and necessary information was taken from the households where the strategies are practiced.

\section{Results}

\subsection{Seasonal and Hazard Calendar}

People of the study area said that temperature is increasing day by day. Summer is hotter and longer now than before. In the March the atmosphere remains too hot and there is evidence of drought. Accordingly, they perceive that monsoon season has irregular now. There is no time table for rainfall. Sometimes extreme rainfall occurs which crosses the previous records. Sometimes no rain is found. In the dry season lack of rainfall causes drought and the crop field becomes cracked. Among 145 respondents 130 people said they observe rising temperature and irregular rainfall, 10 people said there is no change and 5 people said they don't know about this.

Cyclone is the main disaster event in this area. In the present situation, cyclones occur mainly in the months of April to May and mid-July to November. Floods are caused by storm surges in the months of July to October, whereas in the months of late December to April there is high salinity levels in this area due to tidal fluctuation and water scarcity of the river. After cyclone Aila, the salinity concentration increased. River erosion is one of the main hazards in this area. Extreme rainfall is seen in the months of mid-June to September and after heavy rainfalls water logging problem arises due to lack of drainage system. Table 1 shows some details about the common disasters in the study site.

Table 1. Disaster characteristics of the study area

\begin{tabular}{|l|l|l|l|l|}
\hline Disasters & Frequency & Magnitude & Extent & Damage \\
\hline Cyclone and storm surge & Every year & $\begin{array}{l}\text { Aila-high } \\
\text { Sidr-medium }\end{array}$ & 1-2 days & Life, shelter, and property \\
\hline Flood & Every 9 or 10 years & $\begin{array}{l}2009-\text {-high } \\
1998-l o w \\
1988-h i g h\end{array}$ & days \\
\hline Salinity Intrusion & Every year & Mar-April: high & 5 months & Drinking water source, land \\
\hline River erosion & Every year & Aug-Sep: high & 6 months & Shelter, land \\
\hline Excessive rainfall & Every year & June-Aug: high & $2-3$ months & Standing crop, cattle food \\
\hline Water logging & Every year & June-Aug: high & 7 days & Crops and fishes \\
\hline Drought & Every year & Mar-April: high & months & Crops and fishes \\
\hline
\end{tabular}

(Source: FGD and KII 2013).

\subsection{Adopted Strategies Immediate after Cyclone Aila}

There was major infrastructure damage, including the loss of many homes. Therefore, after the cyclone the inhabitants of this region were forced to take accommodation on the roads or the dams. They built temporary huts $[19,24]$. Since many polders were damaged on the southwest coast at many points due to wrecked embankments and consequently flooding of most of the settlements, many people could not resettle in the 
original location or rebuild their homes. Only once the dams were repaired a few months later did the inhabitants begin to return to their old places $[19,24]$. During construction or renovation of houses some households shifted their homes to high positions or changed their materials so that the houses can cope with a future cyclone. The families that had an area for farming or shrimp farming, their farmland or shrimp farming were trying to rebuild their shrimp-farm Households had also taken several initiatives to restart the agricultural production. Sometimes the farmers used their farmland for lime to reduce the penetrating salt in the soil or they built new bypass roads for the shrimp farming to get rainwater. Households were trying to overcome the damage of the cyclone with its indigenous strategies. They tried to ensure survival through individual and collective initiatives.

As with other disasters, it was not possible to repair the damage only with residents of the affected region. It took organizational and material support from outside in order to repair the damage. After the cyclone, as well as in emergency time, people got support from various governmental organizations and NGOs. The local NGOs with the help of international organizations carried out different relief and rescue operations; they offered food, drinking water, medical care, etc. in the emergency situation. After the emergency period, the NGOs began reconstruction efforts with roads and dams. To address problems with temporary livelihoods NGOs have offered a project called "food for work". In this project, people worked to repair the damaged roads or dams or rebuild broken dams and for that they received rice or wheat instead of money. Others were given money for the construction of infrastructure (roads, dams). The NGOs have also given some households construction materials to rebuild their homes. In addition, NGOs and government organizations rebuilt or repaired coastal infrastructures such as cyclone shelters.

People perceived their survival to be based on these construction projects and this unfortunately led to the destruction of some projects. It seemed that they had built a dam during the day only to destroy it at night to ensure regular security of income. They thought if the dam is constructed they would have nothing to work on.

\subsection{Selling out Own Resources}

The most applied way to recover the disadvantageous situation was through the sale of resources or assets $[29,31]$. Similar observations were also found in the studied communities. It shows that $17.4 \%$ of the respondents sold their resources to cope with the adverse situation induced by cyclone. $66.3 \%$ of them sold their cattle and other livestock, because of monetary urgencies and the burden of a shortage of fodders and adequate shelters. 59.6\% sold their broken or even non-broken trees and plants (timber or wood plants) and only 5.9\% sold their ornaments or other household assets like TV, Mobile phone, radio etc. None of them sold their land.

\subsection{Changes in Occupation}

$28.5 \%$ of the people who had sold their assets after cyclone had changed their income sources. Only 3\% of them had reported that changes in income sources had improved their economic solvency. $81.5 \%$ of those who had sold off their assets had reported that they had taken out loans/credit (ranging from 2,000 to 25,000 BDT) from different sources: $69 \%$ from NGOs, $13 \%$ from local money lenders, $12 \%$ from their relatives and only $6 \%$ from local public and private Bank. Furthermore, they needed to migrate or commute to nearer cities to overcome the adverse situation. Field data shows that $29.3 \%$ of the respondents needed to move. It was seen here that the sale of assets was not enough to compensate their adverse situation after cyclone. Temporary or permanent occupation changes draw a new dimension to the occupational structure of the society. Field data shows 14\% (218 respondents) of the total sample changed their occupation in the aftermath of the cyclone. Though their statistical representation is relatively small in context of the total sample, this study considered this issue with great importance. An increasing trend of occupational pattern defines the social dynamics and the future of the societal structures. Shrimp-farming and salt-farming sectors also reported declining trends. Causes of their changes of occupation describe the issues related with long-term inundation of shrimp farm and paddy fields. While the increased number in fishing also support this cause of long-term inundation. It was observed during field survey, peoples who could not introduce themselves as 'fishermen' at day-light but in the dark they fished and sold fishes for their survival. It is important to mention here, the fishing profession is not socially welcomed in Bangladesh, as they are a specific social groups who are called as "Jeley" (i.e. fishermen) and possessed their own social norms and customs that is mostly different from other social groups. Historically, fishermen were lowcaste Hindu communities in Bangladesh, though at present a huge number of Muslims are fishermen. Increased number in day labour, wage-workers or rickshaw pullers hints the scarcity of income opportunities in the affected areas aftermath cyclone. While the increased number of business sectors explained the temporary business opportunities, for example construction of sanitary pitlatrines was reported by some individuals. They started such business with their own investments or had taken credit from NGOs. Increased people in services or job also indicate the temporary supervisory working opportunities in different rehabilitation and reconstruction programs of different stakeholders. For example, for the reconstruction of embankments, the local/national level NGOs recruited few local youth to supervise the construction works.

\subsection{Involvement with Micro-credit}

To reduce the dependency on micro-credit program, it is important to identify the characteristics of the respondents (21.3\%) of those who did not take any credit/loan aftermath cyclone. And it is also necessary to analyze their ways of recovery for the future adaptation planning. $82.8 \%$ of them got emergency supports from different stakeholders within 1 to 14 days after cyclone. The emergency supports continued from 15 to 155 days for them. With that supports they could maintain their families ranging from 7 to 70 days. Thus it indicates a huge amount of emergency aid collections by them. In one hand, the amount and duration of emergency aid supports can prohibit them to take micro-credit. On the other hand their richness can open up new options to recover the 
adverse situations. The local branch manager of Shushilan NGO at Munshigonj, Shyamnagor, Satkhira explained, "loan would help the helpless to survive even in the odd of nature, because it creates self-employment, still this is not the scenario all the time. There are some loan packages in what disaster suffering people can take loan and can try to recover their loss. These programs are like for repairing or building new house, buying cattle, crop insurance etc, still in the real situation is that, only politically preferred or economically affluent people could get that loan. Other people had to be satisfied with the existing entrepreneurship loan which they used to recover their loss in the sudden disaster".

If they do not take any credit, how did they adapt with the adverse situation? Field data shows that none of them changed their income sources, only $15.1 \%$ sold their assets, and $34.7 \%$ migrated to nearby cities. Therefore, changing income source was not their choice. As it was discussed earlier that $78.5 \%$ of this respondents' category can be termed as 'rich', they had enough savings and assets. Thus, living on their savings was one of the best possible options for them. Another cluster is those who represent $21.5 \%$ of this respondents' category. They were unemployed and had chosen to migrate in nearby cities for alternative income sources.

\subsection{Migration as Adaptation}

The evidence from the group discussion is that high income groups were much less likely than other groups to migrated or be displaced. However, migration was also avoided by some poorer income groups. The causes behind their avoidance were to benefit from government and NGO relief schemes or to receive support from affluent families in the villages. Income constraints prompted families to decide to move to the nearest city and to discover income alternatives. Those who moved away from their original locality were excluded from both governmental and NGO relief schemes. "If you want to have some relief goods, your name should be put on the list of NGO officer" said Laksmi Rani, 32 years old, villager of Noabeki of Atulia union. She also added, "My husband has gone Satkhira for pulling Rickshaw. Nobody is here for me and for my children; none can put our name on the NGO list. What shall we do? How long can we survive without food? May be, we must go to my husband in Satkhira". While humanitarian relief addressed some of the immediate concerns of the cyclone victims like food supply, water and sanitation, primary health care etc., a lack of long-term and sustainable solutions to their problems might originate the issues linked to migration and displacement. Immediately after the cyclone there was a lack of income sources, though few jobs were available for the community people, for example - the earth-work activities, reconstruction of embankments, roads, bridge, culverts etc. To be a worker in those rehabilitation and reconstruction works, one must submit their names to the respective authority (contractors). This naming process required supports from local leaders and also depended on the status of social networks of the respondents. The respondents' family, who were unable to get enough income sources through locally organized rehabilitation works, were the primary audience of displacement (30\% of the total respondents). Hence, some of their family members (36\% of migrated family members) get involved in government Food for Work programs.

\section{Adopted Strategies: Long-term Perspective}

\subsection{Food Security}

The cyclone Aila inundated the whole area with saline water for a long time destroying almost all freshwater sources. Its severe effect was seen on agriculture thus on local food security. Development of alternative cropping systems became an urgent need in this area. In the study area two types of agricultural products are found now: Paddy (available only during the rainy season) and vegetables (available during the rainy season and early winter). Due to saline soil and lack of irrigation water, farmers were repeatedly failing to grow rice on remaining rice fields. Farmers cultivated saline tolerant rice varieties like BINA-8, BRRI-54. BINA-8. These could be cultivated in the month of June and needed only two months to ripen. BINA-8 is more productive than the ordinary rice $12-13$ sacks per bigha while ordinary rice variety BR-11 is 7-8 sacks per bigha. The new variety BRRI-54 is now cultivated in the area. BRRI-54 is also a saline tolerant variety, but its yield was not available during the study period. Most of the people identified one problem of BINA-8 cultivation i.e. this variety ripens within 2 months and then cutting of the paddy hampers the newly planted crops when BINA-8 is cultivated between two plots of other varieties. People now cultivate vegetables on the raised homestead in the rainy season and early winter. This meets their daily vegetables demand. Farmers use earthen vessels and pipes in a drip irrigation system to cultivate vegetables on the dykes around the fish-farms. Fresh water is used here. Continuous slow water supply from this system helps vegetables to grow on the dykes.

\subsection{Drinking Water Management}

Due to poverty most of the people can't harvest rain water. They store rain water in earthen vessels. Those who have their own tank can store rain water for 3-6 months. Those who have earthen pots store rain water for 2 days to 1 month. A special type of tube well has been installed by a pond to purify contaminated pond water and make it available to the people. It is not an ordinary tube well. It is called an artificial aquifer tube well due to its resemblance with underground aquifer. Practical Action Bangladesh and ADB provided funds to establish an artificial aquifer tube well in the Atulia union. One tube well can supply water for 200 households. The supply of water is discontinued for 2-3 months in a year due to cleaning purposes. The representative of Practical Action Bangladesh told that a microbiological test was done by the NGO FORUM laboratory and the result was acceptable. People preserve the ponds which contain freshwater. In the dry season people have to use the pond water as there is no alternative option. People have raised the dykes of the pond to protect it from saline water during storm surges. 


\subsection{Housing}

People of this area have been living in houses made of mud walls and golpata roof which is a type of palm leaf. Aila has weakened soil compaction, thus the house wall made of mud. Houses made of golpata are not cyclone resistant. As the cyclone shelters are far away, people often did not want to go there unless severe cyclone warnings were issued. During Aila many people died staying in their houses because the mud walls of their houses were not cyclone resistant. After Aila most of the people built the houses with a new technique. They made sticks from Goran trees or bamboo and made fences with these sticks. Then they applied the mud layer over the fence to make the walls of their houses. This house is more durable than the normal muddy house. People raised the homestead plinth and built the home on it so that these do not get inundated during floods. Raised homestead also protects houses from water logging. Before Aila they did not have raised homestead-plinth which is why many houses were damaged during Aila.

\subsection{Income Options}

Shrimp farming was introduced in this area during the mid-1980s. Shrimp farms have suffered repeatedly from epidemic and low production due to increased salinity after Aila. Few farmers have started new technology based shrimp cultivation. They use the larvae from hachari tomaintain the $\mathrm{pH}$ of water. 40 respondents who practice these techniques are included in the study. In previous years most of the fisherman thought that shrimp is only attacked by the virus and they used fertilizer or ash without consulting with the fisheries officer. Cattle rearing has become impossible due to the crisis of fodder, pastureland and freshwater. Local people have started to rear sheep and goats. Sheep can tolerate tough condition and can eat a wide range of food. Goats also need less food. People have started rearing pigeons in both open and closed methods. Pigeons are less affected by storms and surges. They can feed themselves from different places.

People collect shrimp larvae to earn money. Mostly women are involved in shrimp larvae collection from the river. They also capture numerous non-shrimp fish fries using a very small mesh net. Having no other use they discard these fries on soil, instead of returning back to the river. They sell 80 pieces of shrimp larvae at 100 taka. Social forestry is found in some places of the area. It is the joint venture activities of forest department and the beneficiaries. Forest department gets $40 \%$ and the beneficiaries get $60 \%$ from the profit. Women, especially the Hindu women in this union work in the field. They work in the Gher (i.e. fish farm) to remove weeds that grow and float on the water that pollute the water and hamper the fish production. They get 100 taka per day to clean the Gher. Alternative livelihood options are very few in the study area. Crabs growth is very high and becoming a profitable business in the study area. Demand of crabs in the market encourages the people to cultivate it. Crabs are cultivated in the Gher which are separate from fish farms and mostly women are involved in crab fattening to earn livelihoods. Another innovation is that people have started to save money for the future hazards. They said when disaster attacks they can do something with the saved money. People do not use this money for other purposes. They deposit the money to the nearby Grameen bank or other NGOs.

\section{Prospect and Constraints of Adopted Strategies}

Every adopted strategy has an implication to the society and its acceptance to the community people. How the aforementioned strategies were evaluated by the community is presented in Table 2.

National Economy can be adversely affected by the occurrence of natural disasters. To recover from this situation people can apply various strategies. In this study many strategies are included which are related to disaster risk reduction. Cultivation of saline tolerant rice varieties increases the production of rice compared to the ordinary rice cultivation. The mud walls built with Goran wood or bamboo is more durable than the normal mud walls according to the people. Due to new technology-based shrimp farming, shrimp production has increased; however these are practiced only be a few people because of a general lack of knowledge. Sheep, goat and pigeon rearing are increasing instead of cow rearing. The community has now managed to identify suitable tree species for their changed condition and have started to plant three types of trees like tan, sour and bitter fruit bearing trees which do well in saline area. Alternative livelihood options may reduce the economic vulnerabilities. But alternative livelihood options are very few in this area. NGOs help people to develop livelihoods through improvement plans and activities with the local community to reduce their disaster risks and to adapt to climate change. If people become economically solvent they can reduce the risk of disasters by themselves. People collect the shrimp larvae from river, timber, fish, honey, fuel-wood etc. from Sundarbans. If there were alternative income opportunities, such kind of dependency on Sundarbans could be minimized to save the biodiversity of this natural mangrove forest. Social forestry activities have been initiated in the area. These activities should be enhanced in the whole area so that they may fulfill their fuel demand and also become an income source. Social forestry displays the possible aspects of improvement for a household-based disaster adaptation planning. It helps to identify the family-related domains of disaster response.

\section{Discussion}

Disasters are unavoidable and the daily companion of live in Bangladesh. In recent decades, a total of 102 tornados in the US called for the disbursement of $\$ 1.72$ billion (SDR, 2003), whereas Bangladesh spent approximately $\$ 1$ billion emergency help during cyclone Sidr 2007. It should also be noticed that JDLNA Mission of 11 donors proposed Bangladesh government a \$4 billion program to mitigate natural disasters, which will be implemented in the next 15 years [23]. The intradependency of disaster preparedness amongst rich and poor countries has created a situation where the rich spend for the problems of the poor [33] and thusly has made the poor countries more dependent and redundant upon rich countries and more vulnerable to natural calamities 
$[10,22]$. Therefore, strategies need to urgently be developed to originate from the community itself to offer more sustainable long-term solutions [23]. Accordingly, this study tries to find out alternative strategies of disaster risk reduction strategies in order to tap the initiative of local community, their local knowledge, experiences and culture based on their socio-economic conditions.

Table 2. Comparison between previous and present strategies of adaptation/risk reduction

\begin{tabular}{|c|c|c|}
\hline \multicolumn{3}{|c|}{ Previous } \\
\hline Strategy & Pros & Cons \\
\hline Ordinary rice cultivation & \begin{tabular}{|l|}
-Production level is medium \\
-Does not harm others' crops
\end{tabular} & -Need more time \\
\hline Homestead vegetables cultivation & \begin{tabular}{|l|}
$\cdot$ Low cost \\
$\cdot$ Need less labor
\end{tabular} & $\begin{array}{l}- \text { Lower production } \\
\cdot \text { Can be damaged in water logging }\end{array}$ \\
\hline Only fish cultivation & -Fish production & -Found fish only \\
\hline Rain water use & $\begin{array}{l}\text {-Less contaminated than pond water } \\
\text { •does not contain saline }\end{array}$ & -Not available all the time \\
\hline Use of tube well water & -Available and near the house & -Contain saline and iron \\
\hline Use of pond water & -Near the house & -Causes skin irritation \\
\hline Built house with mud & \begin{tabular}{|l|}
-Less cost \\
-Less labor
\end{tabular} & •Causes life risk during cyclone \\
\hline Built house on normal height & -Does not need extra mud & -During flood and water logging water enter into house \\
\hline Normal shrimp culture & -Income & -Shrimp farms were affected more due to lack of knowledge \\
\hline Rearing cows & $\begin{array}{l}\text { People get milk } \\
\cdot \text {-Cow dung as organic manure }\end{array}$ & $\begin{array}{l}\text {-Cows can't survive in the salty weather } \\
\text {-Need more food }\end{array}$ \\
\hline Take loan to reconstruct the house & -Can get the loan easily & - Money lender can’t give the loan always in necessary \\
\hline \multicolumn{3}{|c|}{ Present } \\
\hline Strategy & Pros & Cons \\
\hline Saline tolerant variety cultivation & $\begin{array}{l}\cdot \text { Production is more than ordinary rice } \\
\text {-Need less time }\end{array}$ & -Need to cultivate in the definite time \\
\hline $\begin{array}{l}\text { Vegetables cultivation in raised } \\
\text { homestead }\end{array}$ & $\begin{array}{l}\text {-More Production } \\
\text {-Become protected from water logging }\end{array}$ & -Need more labor \\
\hline $\begin{array}{l}\text { Vegetables cultivation around } \\
\text { shrimp farms through drip irrigation } \\
\text { System }\end{array}$ & $\begin{array}{l}- \text { Low cost } \\
\text { - One can produce vegetables and fish together } \\
\text {-Need less water }\end{array}$ & $\begin{array}{l}\cdot \text { Need proper } \\
\text { care }\end{array}$ \\
\hline $\begin{array}{l}\text { Rainwater } \\
\text { harvesting }\end{array}$ & \begin{tabular}{|l|}
$\cdot$ Can use for up to 6 months \\
-Does not contain saline
\end{tabular} & -Not available year round \\
\hline Use of Artificial Aquifer Tube well & -Water is more pure than normal tube well & $\begin{array}{l}\text {-Can’t supply in the dry season } \\
\cdot \text {-Needs 2-3 months to clean }\end{array}$ \\
\hline Preserve the dykes of the pond & \begin{tabular}{|l}
-Affect less from water logging \\
-Can supply when rain is absent
\end{tabular} & -Maintenance is tough \\
\hline $\begin{array}{l}\text { Built house with preparing mud and } \\
\text { the stick of bamboo or Goran }\end{array}$ & $\begin{array}{l}- \text { More durable than normal mud wall } \\
\cdot \text {-Less risk from the wall made of only mud }\end{array}$ & $\begin{array}{l}\cdot \text { Need extra wood or bamboo } \\
\text {-Need to prepare the mud }\end{array}$ \\
\hline Raising homestead plinth & -Safe from flood and water logging & -Need extra mud and labor \\
\hline Technology based shrimp farming & \begin{tabular}{|l|}
-Shrimps are less affected \\
• More Production
\end{tabular} & \begin{tabular}{|l} 
Need to know about parameters like $\mathrm{pH}$, temperature, $\mathrm{DO}$ and \\
their relations \\
$\cdot$-Regular monitoring is necessary \\
\end{tabular} \\
\hline Sheep and goat rearing & \begin{tabular}{|l|}
-Need less food and less place \\
-Profitable
\end{tabular} & $\begin{array}{l}- \text { Need to cultivate saline tolerant grass } \\
\text {-Need to take care }\end{array}$ \\
\hline Rearing pigeons & $\begin{array}{l}\text {-Affected less in cyclone } \\
\text {-Can feed themselves } \\
\text {-Profitable }\end{array}$ & -Sometimes pigeons are lost \\
\hline Collection of shrimp larvae & •Women earn money & $\begin{array}{l}- \text { They destroy other fish fries during larvae collection and may } \\
\text { destroy the biodiversity. }\end{array}$ \\
\hline Social forestry & \begin{tabular}{|l|}
$\cdot$ Beneficiaries get $60 \%$ benefits \\
-Also get the wood and branches of the trees
\end{tabular} & $\begin{array}{l}\text {-Sometimes beneficiaries do not get the benefits because of the } \\
\text { involvement of a dishonest person. }\end{array}$ \\
\hline Cleaning the 'Gher' ( Shrimp farm) & -Women earn money & • Hampers household activities \\
\hline Crab fattening & -Easy way to earn money & - Have to take care \\
\hline Save for future vulnerabilities & -Can use the money in the time of danger & -Need to be careful about the necessary improvement \\
\hline
\end{tabular}

Source: Field survey 2013.

Accordingly, the focus of this analysis is on the relatively less explored topic of the relevance of microcredit as a recovery tool following the cyclone. Mallick et al. [24] stated in their study that the physical infrastructure and livelihood condition of the cyclone Aila affected people were tremendously worse, therefore, they started to sell their own resources, shift from occupation to occupation, take micro-credit from many NGOs, and, in extreme cases, migrate to the cities for alternative income sources. The pattern of displacement which are reported in this study recalls the findings of Mallick \& Vogt [26] and Kartiki [17].
Usually, after a disastrous event, the first and foremost financial sources used to recover the situation are selfassets or insurance, i.e. savings and accumulated assets. Unfortunately, in the developing country like Bangladesh, there is no such kind of insurance available, and even the widespread poverty shows that the survivors did not have enough savings and have to wait for humanitarian aid $[24,33]$. This study has also underpinned the shortages of food, interruptions in water supply and sanitation, electricity and communication and transport services. For this reason, especially in the low-income rural areas, it is common practice to form risk-sharing networks. This is 
why micro-credit is an important recovery tool aftermath disaster [14] Through the comprehensive disaster management program (CDMP) of the government Bangladesh, over 1 million cyclone Aila affected people have now access to safe drinking water, through installing pond-sand-filter (PSF), rain water harvesting (RWH), arsenic removal filter etc., those have also been reported in this study.

In the framework of the present study, it has been observed that earlier emergency experiences [30], coping strategies, traditional skills and local environmental knowledge are important in reducing the impact of hazards. In particular, pre-disaster characteristics and conditions of the victims (e.g., socioeconomic status, gender, marital status, family size, available support networks, etc.) and disaster impacts (e.g., severity of exposure, financial and material loss, displacement of houses etc.) all influence medium and long-term outcomes in the aftermath of the disaster. All these characteristics and conditions can be interpreted as vulnerability indicators of coastal households [19,24,25,30,33].

Current community-based approaches reinforce the idea that social domains of knowledge and action are discrete concepts, on the one hand it shows family domains of knowledge and on the other hand there is action. Each comprises different perceptions and interests to vulnerability and disaster management. Approaching the issue of indigenous practices before designing any adaptation plan will enhance the search for complementarities and win-win situations for disaster planner. Also, such an approach will encourage the promotion of strategies based on the community's actual needs rather than the promotion of those merely accepted. In the latter case, it can be seen as one way of community resilience building.

\section{Conclusion}

This study provides the information on how the local communities change their livelihood strategies in the course of disastrous situations and in the long-run their adopted strategies have been seen as adaptation to the consequences of climate change. Although the government of Bangladesh has been completed many disaster management projects and even now is implementing some projects into an integrated disaster risk reduction and climate change adaptation, there are still now significant challenges on achieving the sustainable development and eradication of poverty. Unless these are achieved it is almost impossible to reduce the dependency on external and donor assistance in postdisaster management. Therefore, there will hardly be any chance to successfully implement the CDMP driven concept of 'resilient community'. Being more optimistic, we propose that the government will be able to undertake risk informed policy planning, program development and financial planning. We optimistically propose that the government will be able to undertake the Vision 2021 is an example of such initiative undertaken by the government to ensure inclusion of disaster risk reduction in the development planning. Inclusion of disaster management literature in national curriculum is also a step forward to build up a disaster resilient community. The country has reduced death and fatalities $\left(1 / 100^{\text {th }}\right.$ from that of 1970s), despite facing increasing trends in damages and exposure (10 times higher than the losses of 1970s). Therefore, the government and other development partners of Bangladesh as well as researchers should consider the movement beyond mortality reduction to livelihood and asset protection in the face of climate change. This is examining what can (and cannot) be done to protect assets, preserve livelihoods and/or replace livelihoods with other (especially non-farm) income earning activities that are not vulnerable to cyclones. This becomes especially important with climate change is expected to increase the severity of cyclones, which may increase. It is critical to remember that it is not only the shock of the wind, rain, and storm surges that have negatively affected the people but also the lingering effects of water-logging, saline intrusion and damaged infrastructure and reduced services.

\section{Acknowledgement}

The primary version of this paper has been presented at $9^{\text {th }}$ IIDS- IIMS International conference at Bonn University, Germany on July 9-11, 2014. Special thanks are given to Ms. Brittany Berger a fellow conservationist and environmental activist in Brazil for her supports in linguistic and grammatical edits. Thoughtful comments from the anonymous reviewers and the journal editor are also sincerely appreciated.

\section{References}

[1] Adger, W. N., Hughes, T. P., Folke, C., Carpenter, S. R., \& Rockström, J. (2005). Social-ecological resilience to coastal disasters. Science (New York, N.Y.), 309(5737), 1036-9.

[2] Afsar, R. (2003). Internal migration and the development nexus: the case of Bangladesh. In Regional Conference on Migration, Development and Pro-Poor Policy Choices in Asia (pp. 22-24). Dhaka, Bangladesh. Retrieved from

http://www.research4development.info/PDF/Outputs/MigrationGl obPov/WP-CP2.pdf.

[3] Ali, A. (1996). Vulnerability of Bangladesh to climate change and sea level rise through tropical cyclones and storm surges. Water, Air, \& Soil Pollution, 92, 171-179.

[4] Bank, A. W., \& Corporate, G. (2014). Risk and Opportunity.

[5] Barrett, C. B., \& Carter, M. R. (2008). Poverty Traps and Social Protection Poverty Traps and Social Protection?, (0804).

[6] Benson, C., \& Twigg, J. (2007). Tools for Mainstreaming Disaster Risk Reduction : Organisations Tools for Mainstreaming Disaster Risk : Disaster Risk : (pp. 1-181). Geneva.

[7] Berkes, F., \& Ross, H. (2013). Community Resilience: Toward an Integrated Approach. Society \& Natural Resources, 26(1), 5-20.

[8] Brien, K. O., Leichenko, R., \& Vogel, C. (2008). Disaster Risk Reduction, Climate Change Adaptation and Human Security Norwegian Ministry of Foreign Affairs Disaster Risk Reduction , Climate Change Adaptation and Human Security.

[9] Brouwer, R., Aftab, S., Brander, L., \& Akter, S. (2007). Socioeconomic vulnerability and adaptation to environmental risk: a case study of climate change and flooding in Bangladesh. Risk Analysis, 27(2), 313-326.

[10] Cannon, T. (1994). Vulnerability Analysis and the Explanation of "Natural” Disasters. In A. Varley (Ed.), Disasters, Development and Environment (1st ed., pp. 14-30). John Wiley \& Sons Ltd.

[11] Dasgupta, S., Huq, M., Sohel Masud, M., Mukherjee, N., \& Pandey, K. (2011). Climate Proofing Infrastructure in Bangladesh: The Incremental Cost of Limiting Future Flood Damage. The Journal of Environment \& Development, 20(2), 167-190.

[12] Dessai, S., \& Wilby, R. (2012). How Can Developing Country Decision Makers Incorporate Uncertainty about Climate Risks 
into Existing Planning and Policymaking Processes? (pp. 1-12). Washington D.C.

[13] Eakin, H., \& Bojórquez-Tapia, L. a. (2008). Insights into the composition of household vulnerability from multicriteria decision analysis. Global Environmental Change, 18(1), 112-127.

[14] Gehlich-Shillabeer, M. (2008). Poverty alleviation or poverty traps? Microcredits and vulnerability in Bangladesh. Disaster Prevention and Management, 17(3), 396-409.

[15] Haque, C. E., \& Etkin, D. (2006). People and community as constituent parts of hazards: the significance of societal dimensions in hazards analysis. Natural Hazards, 41(2), 271-282.

[16] Ingram, J. C., Franco, G., Rio, C. R., \& Khazai, B. (2006). Postdisaster recovery dilemmas: challenges in balancing short-term and long-term needs for vulnerability reduction. Environmental Science \& Policy, 9(7-8), 607-613.

[17] Kartiki, K. (2011). Climate change and migration: a case study from rural Bangladesh. Gender \& Development, 19(1), 23-38.

[18] Khalil, G. M. (1992). Cyclones and Storm Surges in Bangladesh " Some Mitigative Measures. Natural Hazards, 6, 11-24.

[19] Kumar, U., Baten, M. A., Al Masud, A., Osman, K. S., \& Rahman, M. M. (2010). Cyclone Aila: One Year on Natural Disaster to Human Sufferings. Agriculture. Dhaka. Retrieved from http://www.unnayan.org/reports/climate/ailareport_final.pdf.

[20] Lein, H. (2000). Hazards and "forced" migration in Bangladesh. Norsk Geografisk Tidsskrift - Norwegian Journal of Geography, 54(3), 122-127.

[21] Lummen, N. S., \& Yamada, F. (2014). Implementation of an integrated vulnerability and risk assessment model. Natural Hazards, 73(2), 1085-1117.

[22] Mahmud, T., \& Prowse, M. (2012). Corruption in cyclone preparedness and relief efforts in coastal Bangladesh: Lessons for climate adaptation? Global Environmental Change, 22(4), 933943.

[23] Mallick, B. (2011). Necessity of acceptance? Searching for a sustainable community-based disaster mitigation approach - the example of a coastal city in Bangladesh. In L. A. Wallendorf, C. Jones, L. Ewing, \& B. Battalio (Eds.), Solutions to Coastal Disasters 2011 (pp. 753-766). American Soceity of Civil
Engineers (ASCE) and Coasts, Oceans, Ports and River Institute (COPRI).

[24] Mallick, B., Rahaman, K. R., \& Vogt, J. (2011). Coastal livelihood and physical infrastructure in Bangladesh after cyclone Aila. Mitigation and Adaptation Strategies for Global Change, 16(6), 629-648.

[25] Mallick, B., \& Vogt, J. (2011). Social supremacy and its role in local level disaster mitigation planning in Bangladesh. Disaster Prevention and Management, 20(5), 543-556.

[26] Mallick, B., \& Vogt, J. (2012). Cyclone, coastal society and migration: empirical evidence from Bangladesh. International Development Planning Reviewe, 34(3), 217-240.

[27] Ministry of Environment and Forests. (2008). Climate Change Strategy and Action Plan. Strategy. Dhaka, Bangladesh.

[28] Parker, B., \& Kozel, V. (2007). Understanding Poverty and Vulnerability in India's Uttar Pradesh and Bihar: A Q-squared Approach. World Development, 35(2), 296-311.

[29] Paul, B. K. (1995). Farmers' Responses to the Flood Action Plan (FAP) of Bangladesh: An empirical study. World Development, 23(2), 299-309.

[30] Paul, B. K. (2009). Human injuries caused by Bangladesh's cyclone sidr: an empirical study. Natural Hazards, 54(2), 483-495.

[31] Rahman, M. K., Paul, B. K., Curtis, A., \& Schmidlin, T. W. (2014). Linking Coastal Disasters and Migration: A Case Study of Kutubdia Island, Bangladesh. The Professional Geographer, (July 2014), 1-11.

[32] Rahman, S. (2009). Socio-Economic Vulnerability and NeoLiberalism: Lessons from Bangladesh. South Asia Research, 29(3) 235-254.

[33] Saroar, M. M., \& Routray, J. K. (2011). Impacts of climatic disasters in coastal Bangladesh: why does private adaptive capacity differ? Regional Environmental Change, 12(1), 169-190.

[34] Taubenböck, H., \& Geiß, C. (2014). Vulnerability and Resilience Research: A Critical Perspective. International Journal of Disaster Risk Science, 5(1), 86-87.

[35] Vakis, R. (2006). Complementing Natural Disasters Management : The Role of Social Protection Complementing Natural Disasters Management : The Role of Social Protection, (0543). 